\title{
Photoperiodic variations of somatic and germ cell populations in the Soay ram testis
}

\author{
M. T. Hochereau-de Reviers, C. Perreau and G. A. Lincoln* \\ I.N.R.A. - Reproductive Physiology Station, 37380 Nouzilly, France and \\ ${ }^{*} M R C$ Reproductive Biology Unit, 37 Chalmers Street, Edinburgh EH3 9EW, U.K.
}

\begin{abstract}
Summary. Seasonal changes in the Leydig, Sertoli and stem cells (undifferentiated $A_{0}$ and cyclic $A_{1}$ ) spermatogonia and the daily spermatid production were analysed in the testes of adult Soay rams exposed to short days (8L:16D) or long days (16L:8D) for 12 weeks. The total numbers of Leydig, Sertoli and stem cells $\left(A_{0}+A_{1}\right)$ were not affected by the treatments, but the size of the Leydig and the Sertoli cells, the efficiency of spermatogenesis (i.e. the number of male gametes produced by an $A_{1}$ spermatogonium) and the daily sperm production were all significantly reduced in the rams exposed to long days. There was a positive correlation between the concentration of FSH and testosterone and many of the cytological changes consistent with a causal role for these hormones in mediating the effects of photoperiod on the testicular function in the ram.
\end{abstract}

\section{Introduction}

Seasonal changes in the histology of the testis of the ram have been reported previously (Ortavant, 1959; Hochereau-de Reviers, Loir \& Pelletier, 1976; Mortimer \& Lincoln, 1982). During the nonmating season in the spring, there is a decrease in the efficiency of spermatogenesis and daily production of spermatozoa (Ortavant, 1959) and a decline in the size and activity of the Leydig cells (Mortimer \& Lincoln, 1982). These regressive changes are correlated with a reduced secretion of FSH and LH by the anterior pituitary gland (Lincoln \& Short, 1980).

The aim of the present work was to provide a more precise quantitative analysis of the cellular changes in the testes of the ram, and in particular to assess the changes in number of undifferentiated stem cells in the active and regressed testis and to measure the variations in the size of the various cell types. Soay rams were investigated because they have a very marked seasonal testicular cycle which can be readily controlled by exposing animals to short or long daily photoperiods (Lincoln \& Short, 1980).

\section{Materials and Methods}

Animals. Adult Soay rams of 3 years of age were killed after exposure to 12 weeks of short or long days : 5 rams were kept in $8 \mathrm{~h}$ light : $16 \mathrm{~h}$ darkness (Group S) and 6 rams were kept in $16 \mathrm{~h}$ light: $8 \mathrm{~h}$ darkness (Group L). The testes, epididymides, seminal vesicles and ampullae were weighed, and sections of the testes were fixed in Allen B 15 solution (cited by Lillie, 1954) and prepared for histological examination. During the 2 weeks before death a single daily blood sample was collected from each ram on 4 occasions and the plasma was separated and frozen at $-20^{\circ} \mathrm{C}$ until required for the assay of hormone levels.

Quantitative histology. Sertoli and germ cell populations, except $\mathrm{A}_{0}$ spermatogonia, were determined as previously described on 10 cross-sections $(10 \mu \mathrm{m}$ thick) per animal (Hochereau-de 
Reviers et al., 1979). The analysis of the $A_{0}$ spermatogonia population (Hochereau-de Reviers, Courot \& Ortavant, 1976) was done on 30 cross-sections ( $10 \mu \mathrm{m}$ thick). Corrections for shrinkage and nuclear size were done as previously described (Hochereau-de Reviers, 1967). Relative volume of seminiferous tubules, intertubular tissue, Leydig cells, lymph and blood vessels in the intertubular tissue were determined on $10-\mu \mathrm{m}$ sections with an ocular integrator plate on 40 fields per animal (Hochereau-de Reviers et al., 1979).

The stages of the cycle in the seminiferous epithelium were classified according to RoosenRunge \& Giesel (1950) with the longer stages subdivided as in the bull (Hochereau, 1967). The cross-sectional area of the nuclei of 50 Sertoli cells at stages $1 \mathrm{~b}-1 \mathrm{c}, 2 \mathrm{a}, 2 \mathrm{~b}, 3,4,5-6,7$ and 8 were measured for each animal (total number of cells per animal $=400$ ) with a surface planimeter microscope (A.S.M. Leitz). The cross-sectional area of the cytoplasm of 50 Leydig cells at stages $1 \mathrm{a}-1 \mathrm{~b}, 1 \mathrm{c}-2 \mathrm{a}, 2 \mathrm{~b}-3 \mathrm{a}, 3 \mathrm{~b}, 4,5-6,7$ and 8 per animal (400 cells per animal) was similarly determined. Leydig cells were measured only when they were in close contact, by part of their cellular envelope, with the wall of a tubule at the chosen stage and only if they were separated from other tubules at different stages by fibroblasts, lymphatic or blood vessels. They represent less than $50 \%$ of the total Leydig cell population.

The cross-sectional area of the whole cell or of the nuclei of round spermatids at stages $1 \mathrm{a}-1 \mathrm{~b}$ and of old pachytene spermatocytes at stages $3 \mathrm{~b}$ were also measured on at least 20 cells per type and per animal.

Radioimmunoassay. The blood plasma concentrations of prolactin, FSH and testosterone were measured by radioimmunoassays using the method of McNeilly \& Andrews (1974) for prolactin, McNeilly, McNeilly, Walton \& Cunningham (1976) for FSH and Corker \& Davidson (1978) for testosterone. The limits of detection were $0.5 \mathrm{ng} / \mathrm{ml}$ plasma for prolactin using NIH-P-S 9 as reference standard, $20 \mathrm{ng} / \mathrm{ml}$ for FSH using NIH-FSH-S9 as standard and $0.20 \mathrm{ng} / \mathrm{ml}$ for testosterone. All samples were assayed in duplicate in a single assay and the intra-assay coefficient of variation was $<12 \%$ for all assays.

Statistics. The results for the two groups of rams were compared by Student's $t$ test, and the correlations were assessed using rank correlations when the data were not normally distributed.

\section{Results}

\section{Testicular weight and intertubular tissue}

The total weight of the testis and the total volume of the blood and lymph vessels were decreased by almost half in Group $\mathrm{L}$ rams compared to those of rams in Group S. This regression was paralleled by a decrease in the total volume of intertubular tissue and the cross-sectional area of the Leydig cells (Table 1). The total number of Leydig cells per testis did not differ significantly.

\section{Seminiferous tubules and Sertoli cells}

The diameter of the seminiferous tubules but not their length was significantly reduced in Group L rams. The cross-sectional area of the nucleus of Sertoli cells was also reduced but the number of Sertoli cells per testis did not differ (Table 1).

\section{Germ cells}

The total numbers of $A_{0}$ spermatogonia were significantly increased in rams in Group $L$ but the total numbers of $A_{1}$ spermatogonia were significantly reduced; the sum of the $A_{0}+A_{1}$ 
Table 1. Summary of the quantitative histology of testes from adult Soay rams after exposure to short days $(8 \mathrm{~L}: 16 \mathrm{D}$, Group $\mathrm{S})$ or long days $(16 \mathrm{~L}: 8 \mathrm{D}$, Group $\mathrm{L})$ for 12 weeks

\begin{tabular}{|c|c|c|c|c|}
\hline & $\begin{array}{l}\text { Short days } \\
(N=5)\end{array}$ & $\begin{array}{l}\text { Long days } \\
(N=6)\end{array}$ & Significance & $\begin{array}{c}\text { Long-day value } \\
\text { as } \% \text { of } \\
\text { short-day value }\end{array}$ \\
\hline Wt of right testis (g) & $105 \cdot 3 \pm 6 \cdot 1$ & $52 \cdot 7 \pm 4 \cdot 3$ & $P<0.01$ & 50 \\
\hline Total volume of intertubular tissue/testis (ml) & $18.5 \pm 1.7$ & $11 \cdot 3 \pm 1 \cdot 0$ & $P<0.05$ & 61 \\
\hline Total volume of Leydig cells/testis $(\mathrm{ml})$ & $3.4 \pm 0.4$ & $1.9 \pm 0.2$ & $P<0.05$ & 56 \\
\hline Cross-sectional area of Leydig cell $\left(\mu \mathrm{m}^{2}\right)$ & $82 \cdot 7 \pm 5 \cdot 8$ & $51.6 \pm 1 \cdot 2$ & $P<0.01$ & 62 \\
\hline Total no. of Leydig cells/testis $\left(\times 10^{-8}\right)$ & $4 \cdot 0 \pm 0.6$ & $4 \cdot 4 \pm 0.4$ & NS & 111 \\
\hline $\begin{array}{l}\text { Total volume of blood and lymph vessels/testis } \\
(\mathrm{ml})\end{array}$ & $7 \cdot 1 \pm 1 \cdot 1$ & $3 \cdot 5 \pm 0.4$ & $P<0.05$ & 49 \\
\hline Total length of seminiferous tubules/testis (m) & $1752 \pm 102$ & $1442 \pm 138$ & NS & 82 \\
\hline Mean seminiferous tubules diam. $(\mu \mathrm{m})$ & $195.8 \pm 4.0$ & $146.2 \pm 6.5$ & $P<0.01$ & 75 \\
\hline Total corrected no of Sertoli cells/testis $\left(\times 10^{-8}\right)$ & $12.9 \pm 0.6$ & $15.4 \pm 2.8$ & NS & 119 \\
\hline $\begin{array}{l}\text { Cross-sectional nuclear area (stage 2a) of Sertoli } \\
\text { cells }\left(\mu \mathrm{m}^{2}\right)\end{array}$ & $67 \cdot 7 \pm 0.9$ & $46 \cdot 3 \pm 1 \cdot 8$ & $P<0.001$ & 68 \\
\hline Total no. of $A_{0}$ spermatogonia/testis $\left(\times 10^{-8}\right)$ & $2.53 \pm 0.26$ & $3.60 \pm 0.41$ & $P<0.05$ & 142 \\
\hline Total no. of $A_{1}$ spermatogonia/testis $\left(\times 10^{-8}\right)$ & $2.63 \pm 0.23$ & $1.70 \pm 0.35$ & $P<0.05$ & 63 \\
\hline $\begin{array}{l}\text { Daily production of leptotene primary } \\
\text { spermatocytes/testis }\left(\times 10^{-7}\right)\end{array}$ & $65 \cdot 1 \pm 5 \cdot 4$ & $27 \cdot 7 \pm 4 \cdot 6$ & $P<0.01$ & 43 \\
\hline $\begin{array}{l}\text { Daily production of round spermatids/testis } \\
\left(\times 10^{-7}\right)\end{array}$ & $208 \cdot 0 \pm 16 \cdot 3$ & $73 \cdot 5 \pm 12 \cdot 5$ & $P<0.01$ & 35 \\
\hline $\begin{array}{l}\text { Cross-sectional cellular area of pachytene } \\
\text { spermatocytes }\left(\mu \mathrm{m}^{2}\right)\end{array}$ & $146 \cdot 4 \pm 3 \cdot 7$ & $138 \cdot 3 \pm 4 \cdot 6$ & NS & 94 \\
\hline $\begin{array}{l}\text { Cross-sectional cellular area of round } \\
\text { spermatids }\left(\mu \mathrm{m}^{2}\right)\end{array}$ & $65.9 \pm 1.5$ & $56.8 \pm 1.7$ & $P<0.01$ & 86 \\
\hline $\begin{array}{l}\text { Cross-sectional nuclear area of round } \\
\text { spermatids }\left(\mu \mathrm{m}^{2}\right)\end{array}$ & $23.2 \pm 0.8$ & $22 \cdot 0 \pm 0.2$ & NS & 95 \\
\hline
\end{tabular}

Values are mean \pm s.e.m.

spermatogonia was not different in the two groups. The daily production of leptotene primary spermatocytes and round spermatids was decreased in Group L rams. The nuclear area of the various spermatocytes and spermatids was not different in the two groups of rams although there was a slight decrease in the whole cross-sectional cellular area of the round spermatids in Group $L$ rams (Table 1).

\section{Cycle of the germinal epithelium}

The cross-sectional area of the Sertoli cell nucleus varied significantly $(P<0.05)$ according to the stage of the cycle of the seminiferous tubule epithelium (maximum at stage 2 and minimum in tubules at stage 6) in testes from Group S rams, but no cycle was evident in tissues from Group L rams. The size of the Leydig cells did not change significantly related to cycle in the epithelium in either group (Text-fig. 1).

\section{Correlations between testis histology and hormonal measures}

The blood concentration of testosterone (mean of 4 daily samples taken during preceding 2 weeks) was significantly $(P<0.01)$ and positively correlated (rank correlation $\rho=0.77$ ) with the cross-sectional area of Leydig cells, total volume of Leydig cells per testis $(\rho=0 \cdot 89)$ cross-sectional 

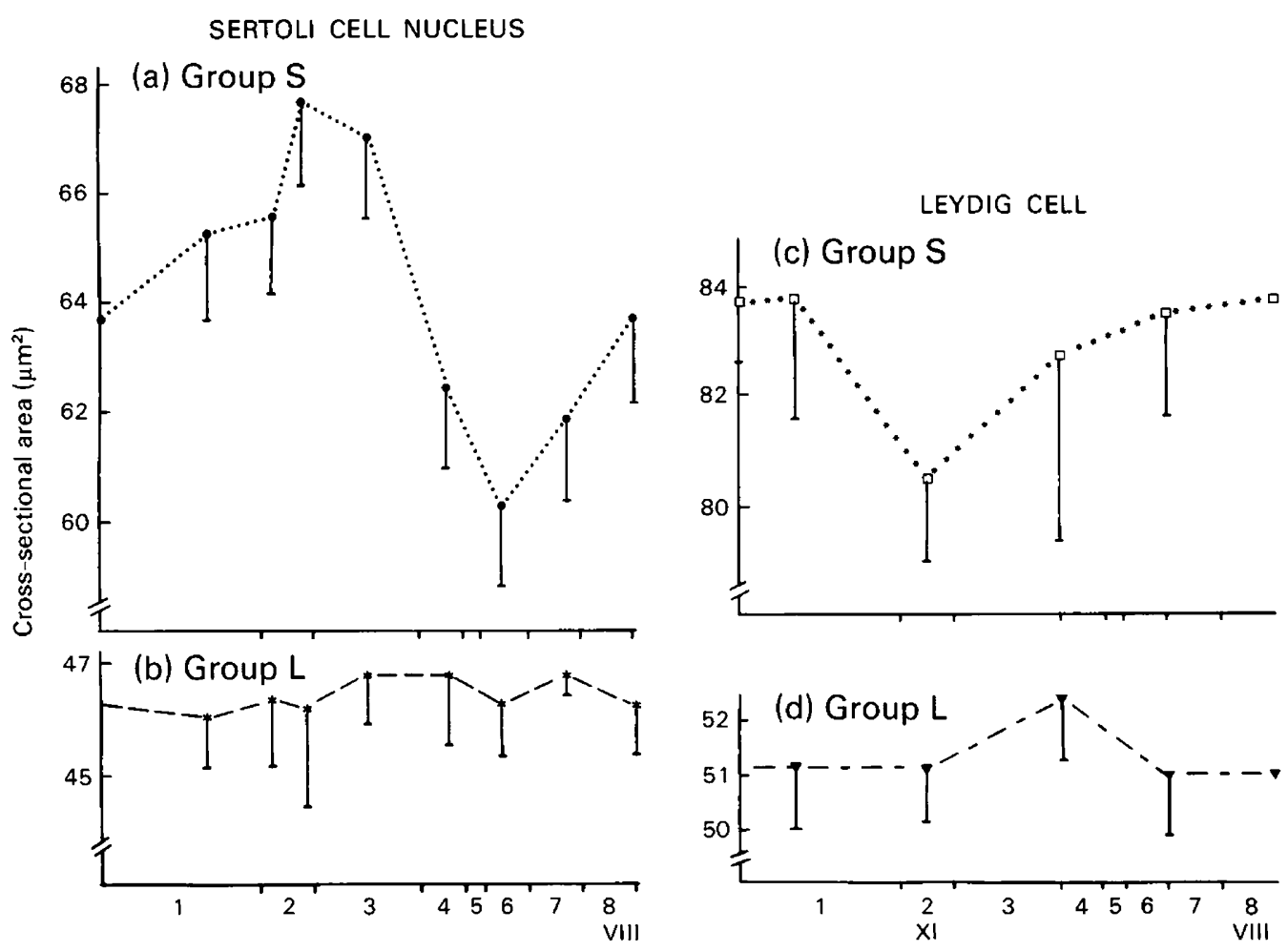

Stages of cycle of the seminiferous epithelium

Text-fig. 1. Variations of the mean ( \pm s.e.m.) cross-sectional areas of $(a, b)$ Sertoli cells and (c, d) Leydig cells related to the stages of the cycle in the seminiferous epithelium in testes from Soay rams exposed to $(a, c)$ short days (Group $S$ ) or $(b, d)$ long days (Group $L$ ).

nuclear area of Sertoli cell $(\rho=0.75)$, daily production of spermatids $(\rho=0.78)$ and cross-sectional cellular area of round spermatids $(\rho=0.71)$. Mean blood concentrations of FSH in the same samples was significantly $(P<0.01)$ and positively correlated with cross-sectional nuclear area of Sertoli cells $(\rho=0.75)$ and cross-sectional cellular area of round spermatids $(\rho=0.72)$, and negatively correlated with the number of $A_{0}$ spermatogonia $(\rho=-0.70)$.

Table 2. Accessory gland weight and blood plasma hormonal concentrations in adult Soay rams after exposure to short days $(8 \mathrm{~L}: 16 \mathrm{D}$, Group $\mathrm{S})$ or long days $(16 \mathrm{~L}: 8 \mathrm{D}$, Group $\mathrm{L})$ for 12 weeks

\begin{tabular}{lcc}
\hline & $\begin{array}{c}\text { Short days } \\
(\mathrm{N}=5)\end{array}$ & $\begin{array}{c}\text { Long days } \\
(\mathrm{N}=6)\end{array}$ \\
\hline Wt of right epididymis $(\mathrm{g})$ & $19 \cdot 9 \pm 0 \cdot 6$ & $13 \cdot 7 \pm 1 \cdot 3^{* *}$ \\
Wt of right seminal vesicle $(\mathrm{g})$ & $7 \cdot 0 \pm 0.7$ & $3 \cdot 8 \pm 0 \cdot 5^{* *}$ \\
Wt of right ampulla $(\mathrm{g})$ & $1.2 \pm 0 \cdot 1$ & $0.9 \pm 0 \cdot 1$ \\
Plasma FSH $(\mathrm{ng} / \mathrm{ml})$ & $221 \pm 68$ & $30 \pm 2^{* *}$ \\
Plasma prolactin $(\mathrm{ng} / \mathrm{ml})$ & $0 \cdot 7 \pm 0 \cdot 1$ & $41 \pm 4 \cdot 8^{* * *}$ \\
Plasma testosterone $(\mathrm{ng} / \mathrm{ml})$ & $17.7 \pm 1 \cdot 8$ & $3 \cdot 4 \pm 1 \cdot 3^{* *}$ \\
\hline
\end{tabular}

** $P<0.01 ; * * * P<0.001$ compared with value for Group $\mathrm{S}$. 
Accesory sex glands

The epididymides and seminal vesicles were reduced significantly $(P<0.05)$ in weight in the rams in Group $\mathrm{L}$ in parallel to the decline in the blood concentration of testosterone (Table 2).

\section{Discussion}

By exposing Soay rams to short days or long days for 12 weeks it was possible to produce groups of animals with active or regressed testes, allowing the nature of the histological changes to be analysed in detail. The changes observed were not qualitatively different from the seasonal changes observed in other ungulates (Ortavant, 1959), although quantitatively they were more extreme than recorded in lle-de-France sheep exposed to decreasing or increasing photoperiods (Pelletier \& Ortavant, 1975).

The seminiferous tubular and intertubular compartments of the testes were affected by the photoperiodic treatments. However, there was no change in the number of Sertoli or Leydig cells, in contrast to the report of seasonal changes in the number of Sertoli cells in the testes of the stallion (Johnson \& Thompson, 1983).

In the Soay, there was a marked change in the size of the nucleus of the Sertoli cells and the volume of the Leydig cells which were expanded under short days and regressed under long days. These cellular changes were associated with the changes in the efficiency of the spermatogenic divisions of the germ cells, such that the daily production of spermatids under long days was only one-third of that under short days. Many of the cellular changes were correlated with the concentrations of FSH and testosterone in the peripheral blood, indicating that the regression under long days was due to the reduced secretion of gonadotrophic hormones.

The total number of specific types of stem spermatogonia also changed in relation to the photoperiod and there was an actual increase in the number of $A_{0}$ spermatogonia in the regressed testes. This is very similar to the changes observed in red deer (Hochereau-de Reviers \& Lincoln, 1978) but different from those in Ile-de-France rams which have a less marked regression of the testes (Hochereau-de Reviers et al., 1976). Since the sum of the $A_{0}+A_{1}$ spermatogonia did not change significantly in the two groups of Soay rams, it is possible that the $A_{0}$ cell type represents an undifferentiated blocked phase of the cellular cycle of the stem cells rather than a cell type distinct from the $A_{1}$ spermatogonia (Lok, Weenk \& de Rooij, 1982). The increase in the $A_{0}$ spermatogonia therefore occurs during long days when these cells are not induced to differentiate and this effect is most obvious when there is a pronounced regression of the testis as occurs in Soay rams and red deer. The seasonal changes in the stem cells observed in this study are probably therefore the result of the decline in LH and FSH concentrations during long days which influences the functional activity of the Leydig and Sertoli cells. Previous studies in which hypophysectomized rams were given replacement therapy with hCG and PMSG have indicated the importance of the gonadotrophins in the early differentiation of the stem cells (Courot et al., 1979).

One novel result revealed in the present study was the way the cycle in the size of the Sertoli cell nucleus relative to the cycle of the seminiferous tubule epithelium was disrupted in the regressed testes (Text-fig. 1). This could indicate that the cyclic changes in the Sertoli cell are induced by the sequence in the maturing germ cells and that the pattern is lost when many of the germ cells fail to develop normally. The maximum nuclear size at stage 2 corresponded to the stage when maximum androgen binding occurs in the rat (Isomaa, Parvinen, Jalle \& Bardin, 1985). The changes in the size of Sertoli cell nucleus occurring in relation to the cycle in the germinal epithelium (seen in the rams in Group S) were relatively small compared to the overall changes related to the photoperiod. We failed to observe significant changes in the size of the Leydig cells in relation to the cycle in the germinal epithelium in the rams in either group. This differs from findings for the rat (Bergh, 1982) but could be explained by the looser structure of the intertubular tissue in the rat. 
In conclusion, we have observed a constancy in the total number of Leydig and Sertoli cells and the sum of the $A_{0}$ and $A_{1}$ stem spermatogonia in the testes from rams kept in long and short photoperiods although the efficiency of spermatogenesis and steroidogenesis changes markedly.

\section{References}

Bergh, A. (1982) Local differences in Leydig cell morphology in the adult rat testis : evidence for a local control of Leydig cells by adjacent seminiferous tubules. Int. J. Androl. 5, 325-330.

Corker, C.S. \& Davidson, D.W. (1978) A radioimmunoassay for testosterone in various biological fluids without chromatography. J. Steroid Biochem. 9 , 373-374.

Courot, M., Hochereau-de Reviers, M.T., Monet-Kuntz, C., Locatelli, A., Pisselet, Cl., Blanc, M.R. \& Dacheux, J.L. (1979) Endocrinology of spermatogenesis in the hypophysectomized ram. J. Reprod. Fert., Suppl. 26, 165-173.

Hochereau, M.T. (1967) Synthèse de l'ADN au cours des multiplications et du renouvellement des spermatogonies chez le taureau. Archs Anat. microsc. Morph. exp. 56, Suppl. 3-4, 85-96.

Hochereau-de Reviers, M.T. \& Lincoln, G.A. (1978) Seasonal variation in the histology of the testis of the red deer, Cervus elaphus. J. Reprod. Fert. 54, 209-213.

Hochereau-de Reviers, M.T., Courot, M. \& Ortavant, R. (1976) Type A spermatogonia in the ram. Sperm Action. Prog. Reprod. Biol. 1, 13-19.

Hochereau-de Reviers, M.T., Loir, M. \& Pelletier, J. (1976) Seasonal variations in the response of the testis and $\mathrm{LH}$ levels to hemicastration of adult rams. $J$. Reprod. Fert. 46, 203-209.

Hochereau-de Reviers, M.T., Blanc, M.R., Cahoreau, C., Courot, M., Dacheux, J.L. \& Pisselet, C. (1979) Histological testicular parameters in bilateral cryptorchid adult rams. Annls Biol. anim. Biochim. Biophys. 19, 1141-1146.

Isomaa, V., Parvinen, M., Jalle, O.A. \& Bardin, C.W. (1985) Nuclear androgen receptors in different stages of the seminiferous epithelial cycles and the interstitial tissue of rat testis. Endocrinology 116, 132-137.
Johnson, L. \& Thompson, D.L. (1983) Age related and seasonal variation in the Sertoli cell population, daily sperm production and serum concentrations of FSH, LH and testosterone in stallions. Biol. Reprod. 29, 777-789.

Lillie, R.D. (1954) Histopathological Technic and Practical Histochemistry. Blakiston Corp., New York.

Lincoln, G.A. \& Short, R.V. (1980) Seasonal breeding: Nature's contraceptive. Recent. Prog. Horm. Res. 36, $1-52$.

Lok, D., Weenk, D. \& de Rooij, D.G.M. (1982) Morphology, proliferation and differentiation of undifferentiated spermatogonia in the Chinese hamster and the ram. Anat. Rec. 203, 83-89.

McNeilly, A.S. \& Andrews, P. (1974) Purification and characterization of caprine prolactin. J. Endocr. 60, 359-367.

McNeilly, J.R., McNeilly, A.S., Walton, J.S. \& Cunningham, F.J. (1976) Development and application of a heterologous radioimmunoassay for ovine folliclestimulating hormone. J. Endocr. 70, 69-79.

Mortimer, D. \& Lincoln, G.A. (1982) Ultrastructural study of regressed and activated testes from Soay rams. J. Reprod. Fert. 64, 437-442.

Ortavant, R. (1959) Déroulement et durée du cycle spermatogénétique chez le bélier. Annls Zootech. 8, $183-244 ; 271-321$.

Pelletier, J. \& Ortavant, R. (1975) Photoperiodic control of LH release in the ram. Acta endocr., Copenh., 78, 435-441.

Roosen-Runge, E.C. \& Giesel, L.O. (1950) Quantitative studies on spermatogenesis in the albino rat. Am.J. Anat. 1, 1-30.

Received 21 June 1984 